\title{
The Impact of Co-management on the Sundarbans Fisheries: Evidence from Sharankhola, Bagerhat, Bangladesh
}

\author{
Muhammad Abdur Razzak ${ }^{1 *} \quad$ Md. Emranul Ahsan ${ }^{2} \quad$ Nazmun Nahar $^{3}$ \\ 1.Department of Aquaculture, Faculty of Fisheries, Patuakhali Science and Technology University, Dumki, \\ Patuakhali, Bangladesh-8602 \\ 2.Department of Fisheries Management, Faculty of Fisheries, Bangabandhu Sheikh Mujibur Rahman Agriculture \\ University, Gazipur, Bangladesh-1706 \\ 3.Bangladesh Institute of Nuclear Agriculture (BINA), Barishal Sub-Station-8210
}

\begin{abstract}
The study was conducted in the Sarankhola, Bagerhat during the period from August to October, 2012 to determine the impact of co-management on the Sundarbans fisheries. At present only one co-management organization is working in the study area. The co-management organization is performing various activities to make fisheries resources of the Sarankhola, Sundarbans sustainable. Co-management initiatives included: awareness raising, alternate income generation, eco-tourism and efforts towards social mobilization. The key regulatory measures and steps of co-management included: Limited Boat License Certificate (BLC), protection of parents hilsa and protection of jatka. Integrated Resources Management Plans (IRMP) was formulated by the Forest Department for sustainable fisheries management of the Sundarbans. IRMP made two major guidelines: One was fisheries resource conservation measures and the other was fisheries improvement measures. Fisheries improvement measures in the study area were weak. The production data revealed that fish production in the Sundarbans is declining in the recent years. It is an important breeding and nursery ground of a wide range of estuarine, offshore and marine fishes and shrimps. Fisheries resource is being degraded due to lack of proper comanagement of the resource. So, effective co-management activity is essential for sustainable fisheries resources conservation-management in the Sundarbans.
\end{abstract}

Keywords: Co-management, Integrated Resources Management Plans (IRMP)

DOI: $10.7176 / \mathrm{JBAH} / 10-2-07$

Publication date: January $31^{\text {st }} 2020$

\section{Introduction}

Co-management of protected area (PA) is a participatory approach to environmental conservation (BorriniFeyerabend et al., 2004) that seeks to enhance both natural resources conservation and local livelihoods. PAs have historically been poorly managed. Moreover, the people living in and around PAs were neither considered nor allowed to participate in PA management.

Bangladesh is a subtropical country which is situated at the apex of the Bay of Bengal, having a vast coastal plain with $710 \mathrm{~km}$ of coastline. The Sundarbans is the largest mangrove forest in the world. It is located at the southwest corner of the Ganges river delta close to the Bay of Bengal. In 1998, UNESCO declared this reserve forest as the world heritage site. The Sundarbans cluster includes the world's largest mangrove forests comprising three Wildlife Sanctuaries, Sundarbans Reserved Forests (SRF) and the Sundarbans Ecologically Critical Areas (ECAs). The SRF is one of the largest coastal belts with a total area of $7,620 \mathrm{~km}^{2}\left(4,143 \mathrm{~km}^{2}\right.$ land; $1,874 \mathrm{~km}^{2}$ rivers, streams and canals; and $1,603 \mathrm{~km}^{2}$ marine zone). The Sundarbans ecosystem supports rich fisheries diversity. Its water-bodies support 27 families and 53 species of pelagic fish, 49 families and 124 species of demersal fish, five families and 24 species of shrimps, three families and seven species of crabs, two species of gastropods, six species of pelecypods, eight species of locust lobster and one family and three species of turtles (IUCN, 1994). About $90 \%$ of commercial fish and 35\% of all fish in the Bay of Bengal rely on the SRF as a nursery for their young life stages. Total stock of fish in that area has been estimated at 2.9-3.7 tons $/ \mathrm{km}^{2}$, which contributes $5 \%$ of the total fish harvest of Bangladesh and the value of that sector has been estimated at US\$ 209.9 million (46,0832 US\$/km ) (Kamal, 1999). The Sundarbans, is highly productive, support large biodiversity and provide a wide range of ecosystem services including flood mitigation, fish breeding and production, livelihoods, climate change mitigation and adaptation, and other socio-economic and recreational functions (IRMP, 2010).

The fisheries resources of the Sundarbans represent the most important non-wood component of the forest, constituting 2 to $5 \%$ of the total capture fisheries production of Bangladesh (Rabbani and Sarker, 1997). Overfishing, particularly collecting Bagda, Penaeus monodon post-larvae (PL) from mangrove and near shore waters to meet increasing demand from shrimp farming and over exploitation of plant and wildlife species are placing increasing amounts of stress on the viability of this delicate ecosystem (Haq et al., 2003).

In the context of the great significance of Sundarbans and its resources especially fisheries, and the past trends in degradation and deterioration, co-management is believed to be an effective means of sustainable 
resource management. This article reviews the role and performance of co-management activities in the fisheries sector in selected sites of the Sundarbans.

This review has the following objectives:

$>$ Review the current co-management practices concerning fisheries management in the study area.

$>$ Assess the impact of Integrated Resources Management Plan (IRMP) on the study area.

$>$ Make some policy and functional recommendations for a more proactive role of co-management institutions for sustainable fisheries management in the Sundarbans.

\section{Materials and Methods}

The fieldwork for the study was conducted in Sarankhola, Bagerhat during the period from August to October, 2012 (three months) to determine the impact of co-management on the Sundarbans fisheries

2.1 Study Area: The empirical investigation was conducted in Sarankhola, Bagerhat which is situated under the Integrated Protected Area Co-management (IPAC) Sundarban Cluster of the Nishorgo Network. The area of Sharankhola Range is about $1,500 \mathrm{~km}^{2}$, consisting of three revenue stations and 12 compartments of which five canals are totally prohibited for fishing throughout the year. Five canals are: Alibanda, Daserbarani office khal, Chandeshwor office khal, Kochi office khal and Kotka khal. Three revenue stations are: Sarankhola, Bogi and Supati. Considering the revenue collection Dublarchar is also important especially for fish drying. Alorkol, Shelar char, Office kella, Meheralli, Majer kella, Manik khali and Narikel baria are important for fish drying for five months of the year.

2.2 Tools and Techniques: Following source of information and tools were used to achieve specific objective.

\begin{tabular}{|c|c|c|c|}
\hline $\begin{array}{l}\text { Sl.N } \\
\text { o. }\end{array}$ & Objectives & $\begin{array}{ll}\text { Nature } & \text { of } \\
\text { information } & \\
\end{array}$ & Sources of information and tools \\
\hline 01 & $\begin{array}{l}\text { Review the current co-management } \\
\text { practices concerning fisheries } \\
\text { management in the study area. }\end{array}$ & Secondary data. & $\begin{array}{l}\text { i) Official document survey } \\
\text { ii) Official statistics } \\
\text { iii) Consultation and interview with IPAC, } \\
\text { IRMP, and DoF officials of the study } \\
\text { area. } \\
\text { iv) Interview with members of Co- } \\
\text { management Committee (CMC). }\end{array}$ \\
\hline 02 & $\begin{array}{l}\text { Assess the impact of Integrated } \\
\text { Resources Management Plan (IRMP) } \\
\text { on the study area. }\end{array}$ & $\begin{array}{l}\text { Composition and } \\
\text { working principles } \\
\text { of IRMP. }\end{array}$ & $\begin{array}{l}\text { i) Interview (administer with semi- } \\
\text { structured questionnaires) } \\
\text { ii) Situational analysis by key informant } \\
\text { iii) Focus group discussions (FGD) } \\
\text { iv) Field observation }\end{array}$ \\
\hline 03 & $\begin{array}{l}\text { Make some policy and functional } \\
\text { recommendations for a more } \\
\text { proactive role of co-management } \\
\text { practices for sustainable fisheries } \\
\text { management in the Sundarbans. }\end{array}$ & $\begin{array}{l}\text { Existing } \\
\text { support } \\
\text { lacking. }\end{array}$ & i) Overall study findings \\
\hline
\end{tabular}

2.3 Interview with member of CMC: CMC interviews were conducted by randomly selected CMC member from the place/gathering where formal Focus Group Discussions (FCD) were organized. CMC interviews were conducted at the specific house of the respective CMC member interviewees. Specific questionnaires were used to conduct the interviews.

2.4 Key Informant (KI) Interview: Secondary information was collected from Key Informants (KI) including Union Parishad Chairman, Member, local elites, and elderly persons. KI interviews were conducted by making prior appointments as well as by spot visits. The interviews were conducted at the offices/ houses of the KI using a questionnaires developed for the purpose.

2.5 Focus Group Discussion: FCD were conducted at public places especially in front of mosques, schools; adjacent tea-stalls or dwelling houses where local people usually gather together. Different information under different indicators was collected using previously developed checklist as well as semi-structured interviews.

2.6 Direct Observation: The team while walking through the area, talked to the local people, discussed many things and made observation on the resources, people's behavior and their activities, etc. It also helped in triangulation of collected information and also helped in generation new questions for interview or discussions. 
2.7 Secondary Information Collection: Some demographic data were collected from IPAC, WorldFish Centre, Forest Department, Fisheries Department offices. Relevant reports and documents were consulted and information was used whenever necessary.

\section{Results and discussions}

3.1 Major co-management

3.1.1 Significance, nature and forms of major co-management practices: At present there is only one comanagement organization in the study area, named Sarankhola Co-management Organization (SCMO). SCMO contributes to sustainable natural resource management and enhanced biodiversity conservation in targeted forest and wetland PAs with the goal of preserving the ecological bio-diversity while promoting equitable economic growth and strengthening environmental governance. Total numbers of council members are 56 and committee members are 24. Total numbers of village conservation forums are 21 and forum members are 3,354. Since its formation, SCMO has taken up several co-management activities with the aim of sustainable natural resource management in the area. SCMO's working area is about 31,227 ha, spreading over one Range Office, three Station Offices, one Upazila, two Unions, and 20 villages/paras.

3.1.2 Awareness raising: The co-management project has given considerable efforts and zeal in running awareness raising campaigning in the locality-focusing mainly on biodiversity value, importance of alternative income generation, sustainable fisheries management and resource extraction, etc. These activities seem to have had a positive impact in the locality; the community members' general level of understanding on the sustainable resource management, as the field observations suggest, is sound.

3.1.3 Alternate Income Generation: Before the launch of co-management activities in the area, nearly all fishermen were fully dependent on the extraction of Sundarbans fisheries. The co-management project has inspired local fishermen to try more efficient production systems such as aquaculture and cage culture. Selected fishermen were provided with fish/shrimp nursery management materials, and support to re-excavation of ponds. 3.1.4 Eco-Tourism: Eco-tourism in the co-management working sites already exists on a limited scale, and the enterprise offers good prospect for providing an important alternative source of income for the local communities and the FD. The goal is eco-tourism and generating funds for conservation of the PAs, create new jobs and enterprises within the local population, and promote a sense of pride in the knowledge of biodiversity, local history, and the changing traditions. Having training received from the co-management project, several local community members are working as tour guides.

Every year the IPAC project arranges foreign tours (exposure) for the members of the Co-management committee. One such visitor is Abul Aslam (Tuhin) who visited to the Indian Sundarbans, 24 Pargona, Holdia, West Bengal, India. With such co-management efforts the pressure on the Sundarbans fisheries has reduced to some extent in the recent years. They suggested building up eco-friendly and community-based resorts and associated infrastructural facilities for paving the way for extension of this promising enterprise.

3.2 The key regulatory measures and steps: The co-management system introduced some regulatory measures and steps in the study area towards sustainable management of the surrounding ecosystems. These are briefly described below:

3.2.1 Limited Boat License Certificate (BLC): Before starting Co-management there was no BLC limitation. Anyone who could pay the fees was able to secure the BLC and thereby exercise practically unlimited right to fishing. Over exploitation was common and rampant. Currently, under the co-management system the number of BLC has been made limited to 3,000 per Range.

3.2.2 Protection of Hilsa spawning: For higher production of hilsa, the government has prohibited all kinds of hilsa harvesting in four major breeding locations for 11 days during peak spawning season every year. Local administration, Department of Police and Department of Fisheries (DoF) personnel are mandated to implement this fishing restriction. The co-management system also supports this move, and runs its own awareness and abiding activities targeting local fishers. This has contributed to the reduction of hilsa harvesting in the peak breeding season.

3.2.3 Protection of Jatka: The government has also prohibited all kinds of jatka (baby hilsa) harvesting during 1 November to 31 May in five major jatka grounds. The co-management is also collaborating with the local administration and Departments of Police and Fisheries to save the jatka population.

3.2.4 Poison Fishing: Application of poison is a highly destructive fishing method in the canals of the Sundarbans. It has been more prominent in the East Division. Normally highly toxic agricultural pesticides are used. The poison fishing is extremely detrimental to the fisheries as it affects to all aquatic organisms including the fishes of all life stages. The quantity of catch is also high. By the initiative taken by Co-management, poison fishing is now decreasing. 


\subsection{Status of Integrated Resources Management Plans (IRMP):}

3.3.1 Formation of IRMP: In August 1997, a five year Conservation Management Plan (CMP) was prepared by Rosario (1997) for the three wildlife sanctuaries, and in January 1998 a 12 year Integrated Forest Management Plan (IFMP) for the SRF was prepared by Canonizado and Hossain (1998) supported by the Forest Resources Management Project (FRMP). Upon expiration of the 12 years working period of the IFMP (1998-2010), the FD requested technical support to revise the IFMP. At the same time, an agreement was reached with USAID (United States Agency for International Development), FD, European Union and IPAC to move ahead with assistance in preparing a Strategic Management Plan (SMP) as recommended in the SEALS (Sundarbans Environmental and Livelihood Security) project preparation report. The IRMP is formed based on the SMP. This IRMP is developed through a consultative process with the FD, DoF and the Ministry of Environment and Forest (MoEF). This IRMP for the SRF and its surrounding landscape is thus the result of numerous discussions and meetings with the FD, DoF and Department of Environment (DoE); local stakeholders including CoManagement Organizations (CMOs); civil society members; USAID; USFS (United States Forest Service), and IPAC project.

One-third of the SRF is wetlands, which play vital role in enhancing human welfare by providing livelihoods, climate change mitigation and adaptation and securing other life supportive ecological and food security services. IRMP made two major guidelines for sustainable fisheries management. The $1^{\text {st }}$ one is fisheries resource conservation measures including fishing area ban, fishing ban during breeding season, seasonal gear ban, complete gear ban, mesh size control, boat license certificate (BLC) limit, fishing duration, fish size limit and species ban. The $2^{\text {nd }}$ one is fisheries improvement measures including habitat restoration, establishing fish sanctuaries, pond aquaculture, awareness raising, and monitoring of fisheries stocks, production trend, fisheries marketing, livelihoods opportunities and regular production.

3.3.2 IRMP guidelines and present status of fisheries: Here is a brief about the regulatory measures being implemented by the co-management authorities and the observed consequences (Table 1).

Table 1: Regulatory measures by IRMP and observations on compliance.

\begin{tabular}{|c|c|c|}
\hline Sl. No. & Regulatory Measures & Observations on compliance \\
\hline \multicolumn{3}{|c|}{ Fisheries resources conservation measures } \\
\hline 01 & $\begin{array}{l}\text { Fishing area ban } \\
\text { All water bodies in the existing three } \\
\text { and proposed wildlife sanctuaries. } \\
\text { Permanent fishing ban by the FD } \\
\text { enforced in the } 18 \text { canals of the SRF. } \\
\text { Canals }<25 \text { feet wide within three km } \\
\text { area of the FD permanent Camp } \\
\text { office/Petrol office located throughout } \\
\text { the Sundarbans. }\end{array}$ & $\begin{array}{l}\text { Permanent fishing ban id practiced in the Sundarbans East } \\
\text { Wildlife Sanctuary and five canals. Fishermen having BLC } \\
\text { often tries fishing in the prohibited canals. }\end{array}$ \\
\hline 02 & $\begin{array}{l}\text { Fishing ban during breeding season } \\
\text { Fishing ban in all canals during the } \\
\text { months of July and August. } \\
\text { Fishing ban in the beels/chatals of the } \\
\text { Sundarbans during February-March. }\end{array}$ & $\begin{array}{l}\text { Current situation is better than any previous time. Often } \\
\text { fishing is practiced illegally during breeding season due to } \\
\text { lack of enough manpower of the FD and collaboration with } \\
\text { Fisheries Department and co-management committee. }\end{array}$ \\
\hline 03 & $\begin{array}{l}\text { Seasonal gear ban } \\
\text { Use of Ilish jal/Fash jal is banned in } \\
\text { September and October. }\end{array}$ & $\begin{array}{l}\text { Present situation of seasonal gear ban is working } \\
\text { impressively well. Local administration, DoF, Co- } \\
\text { management committee are jointly working with the FD for } \\
\text { thuis seasonal gear ban implementation. So the performance } \\
\text { on seasonal gear ban is excellent. }\end{array}$ \\
\hline 04 & $\begin{array}{l}\text { Complete gear ban } \\
\text { Behundi/bebdi/bendi/bhasan jal (a kind } \\
\text { of set bag net)." }\end{array}$ & $\begin{array}{l}\text { This gear is very harmful to the Sundarbans fisheries. Using } \\
\text { of set bag nets could not be stopped completely but its rate of } \\
\text { use is moderate at the moment. }\end{array}$ \\
\hline 05 & $\begin{array}{l}\text { Mesh size control } \\
\text { Fishing nets with mesh }<15 \mathrm{~mm} / 1 \text { inch } \\
\text { (knot to knot at stretch condition) are } \\
\text { not allowed for fishing. } \\
\text { Using insecticides and poison for fishing } \\
\text { is strictly prohibited }\end{array}$ & $\begin{array}{l}\text { Use of nets having }<15 \mathrm{~mm} \text { has reduced drastically as } \\
\text { compared to the situation of rampant use before the co- } \\
\text { management initiatives. } \\
\text { It is a highly destructive fishing method in the canals of the } \\
\text { Sundarbans. Sometimes fishermen catch fish and prawn from } \\
\text { the canal by using poison. Due to lack of test kits for } \\
\text { monitoring presence of poison in the water it cannot be } \\
\text { proved and not possible to take any action against the fishers. }\end{array}$ \\
\hline
\end{tabular}




\begin{tabular}{|c|c|c|}
\hline SI. No. & Regulatory Measures & \begin{tabular}{|c|} 
Observations on compliance \\
\end{tabular} \\
\hline 06 & $\begin{array}{l}\text { Boat License Certificate (BLC) limit } \\
\text { The maximum number of annual BLC } \\
\text { issuance is around } 96,000(8 \times 12,000) \\
\text { for the entire Sundarbans and equally } \\
\text { distributed for the four Ranges } \\
(4 \times 3,000) \text {. }\end{array}$ & $\begin{array}{l}\text { It starts from fiscal year 2012-13. The FD is maintaining it } \\
\text { strictly for sustainable Sundarbans fisheries. The idea of } \\
\text { limited BLC numbers came out from co-management } \\
\text { institution initiatives. }\end{array}$ \\
\hline 07 & $\begin{array}{l}\text { Fishing duration } \\
\text { The maximum fishing duration against } \\
\text { a BLC permit is seven days. The days } \\
\text { will be counted from the date of permit } \\
\text { issuance and ends on the day of permit } \\
\text { submission. }\end{array}$ & Forest Department is maintaining it strictly. \\
\hline 08 & $\begin{array}{l}\text { Species ban } \\
\text { Pangas (Pangasius pangasius) and Sea } \\
\text { bass (Lates calcarifer) is banned on } \\
\text { each alternating year. } \\
\text { Ilish (Tenualosa ilisha) fishing is } \\
\text { banned in September - October. } \\
\text { Crab harvesting is banned during } \\
\text { January - February." }\end{array}$ & $\begin{array}{l}\text { Some fishermen try to violate this regulation (catching } \\
\text { banned species in a particular time) due to lack of manpower } \\
\text { of the FD and DoF. }\end{array}$ \\
\hline 09 & $\begin{array}{l}\text { Fish size limit } \\
\text { Catching of Ilish and Pangas }<23 \mathrm{~cm} \text { is } \\
\text { prohibited during November-April. } \\
\text { The minimum weight of harvested male } \\
\text { crab should be } 200 \mathrm{~g} \text { and for female is } \\
120 \mathrm{~g} \text {. }\end{array}$ & $\begin{array}{l}\text { Catching of }<23 \mathrm{~cm} \text { ilish called jatka are now avoided by } \\
\text { the fishermen due to enough vulnerable group feeding } \\
\text { (VGF) assistance and enough monitoring. } \\
\text { Monitoring of crab weight is not possible due to lack of } \\
\text { manpower. }\end{array}$ \\
\hline \multicolumn{3}{|c|}{ Resource improvement measures } \\
\hline 01 & $\begin{array}{l}\text { Habitat Restoration } \\
\text { In case of rivers and canals, name, } \\
\text { origin, end point, length, width and } \\
\text { water depth should be determined. } \\
\text { In case of chatal/ beel, name, area and } \\
\text { perennial status would be recorded on } \\
\text { compartment basis. }\end{array}$ & Nobody is performing any task regarding habitat restoration. \\
\hline 02 & $\begin{array}{l}\text { Fish sanctuaries } \\
\text { In addition to the } 18 \text { khals where fish } \\
\text { catching has been banned by the FD, } \\
\text { more fish sanctuaries should be } \\
\text { established with the help of CMCs. }\end{array}$ & $\begin{array}{l}\text { Still five canals are being used as fish sanctuaries without } \\
\text { any management. }\end{array}$ \\
\hline 03 & $\begin{array}{l}\text { Pond aquaculture } \\
\text { More fish ponds should be encouraged } \\
\text { in the interface landscape in order to } \\
\text { lessen biotic pressure on the Sundarbans. }\end{array}$ & The FD is not taking any steps on pond fish culture. \\
\hline 04 & $\begin{array}{l}\text { Awareness raising } \\
\text { Effective awareness and motivation is } \\
\text { required among the fishers and local } \\
\text { people. }\end{array}$ & The FD is not taking any steps on awareness raising. \\
\hline 05 & $\begin{array}{l}\text { Fisheries stock assessment and } \\
\text { production trend } \\
\text { A comprehensive study should be done } \\
\text { at five years interval to look at the } \\
\text { following issues: } \\
\text { - Total production of fish and other } \\
\text { aquatic organisms. } \\
\text { - Species wise production. } \\
\text { - Range-wise fish production. }\end{array}$ & $\begin{array}{l}\text { To adjust BLC numbers it is very essential to } \\
\text { assess the fisheries stock and production trend. But } \\
\text { the FD is not in a position to take any steps due to } \\
\text { inadequate manpower. }\end{array}$ \\
\hline
\end{tabular}




\begin{tabular}{|c|c|c|}
\hline Sl. No. & Regulatory Measures & Observations on compliance \\
\hline 06 & $\begin{array}{l}\text { Fish marketing } \\
\text { Possible steps for establishing fish } \\
\text { markets. }\end{array}$ & $\begin{array}{l}\text { It is very essential to get actual price by selling fisheries } \\
\text { products by the fishermen for improving their socio- } \\
\text { economic condition. }\end{array}$ \\
\hline 07 & $\begin{array}{l}\text { Regular production monitoring } \\
\text { The FD should have a regular catch } \\
\text { monitoring programme on production } \\
\text { and biodiversity measures, which will } \\
\text { generate basic information for } \\
\text { management decisions. }\end{array}$ & The FD is not performing any task on it. \\
\hline 08 & $\begin{array}{l}\text { Livelihoods opportunities } \\
\text { In reducing pressure on the } \\
\text { Sundarbans, the fishers should be } \\
\text { supported with conservation linked } \\
\text { alternate income generating } \\
\text { programmes. }\end{array}$ & $\begin{array}{l}\text { Fish culture and other alternate opportunities like VGF card } \\
\text { and food security programs might be livelihood } \\
\text { opportunities but no steps are being taken by the FD. }\end{array}$ \\
\hline
\end{tabular}

3.4 Major offences and punishments: The major offences and corresponding punishment at the study area are shown diagrammatically in Fig. 1. As noted earlier, poison fishing is a highly destructive fishing method used in the canals at the study area. The poisons are those which are used in agriculture as insecticides and mainly three in numbers. The poisons are liquid and usually marketed in bottles and are from India. The poison fishing is very detrimental to the fisheries as it affects to all aquatic organisms. The poison fishing causes huge fisheries damage. It can be assumed visually that fishermen are harvesting fish by poisoning but due to lack of test kits it cannot be proved. So, the FD cannot take actions against them. Fishing by banned gear like behundi and current jal is also another crucial offence. Besides, jatka harvesting, berried hilsa harvesting and P. monodon PL collection are also very harmful for the study area.

Punishment includes destroying of gear, suing legal cases/litigations, collecting fine and jail. Offences related to fishing are recorded under compounded offence report (COR) and a fine is imposed and collected from fishers for such offences in the study area. Monitoring and following up the cases are time consuming and cumbersome. Many cases eventually end up in limbo or getting dismissed due to lack of follow up and monitoring by the FD.

In 2010-11, the number of suing case was one and in 2011-12 the number of suing cases were eight (personal communication Forest Department, Sharankhola, 2012). This result represented that the offences are in an increasing trend in the study area.

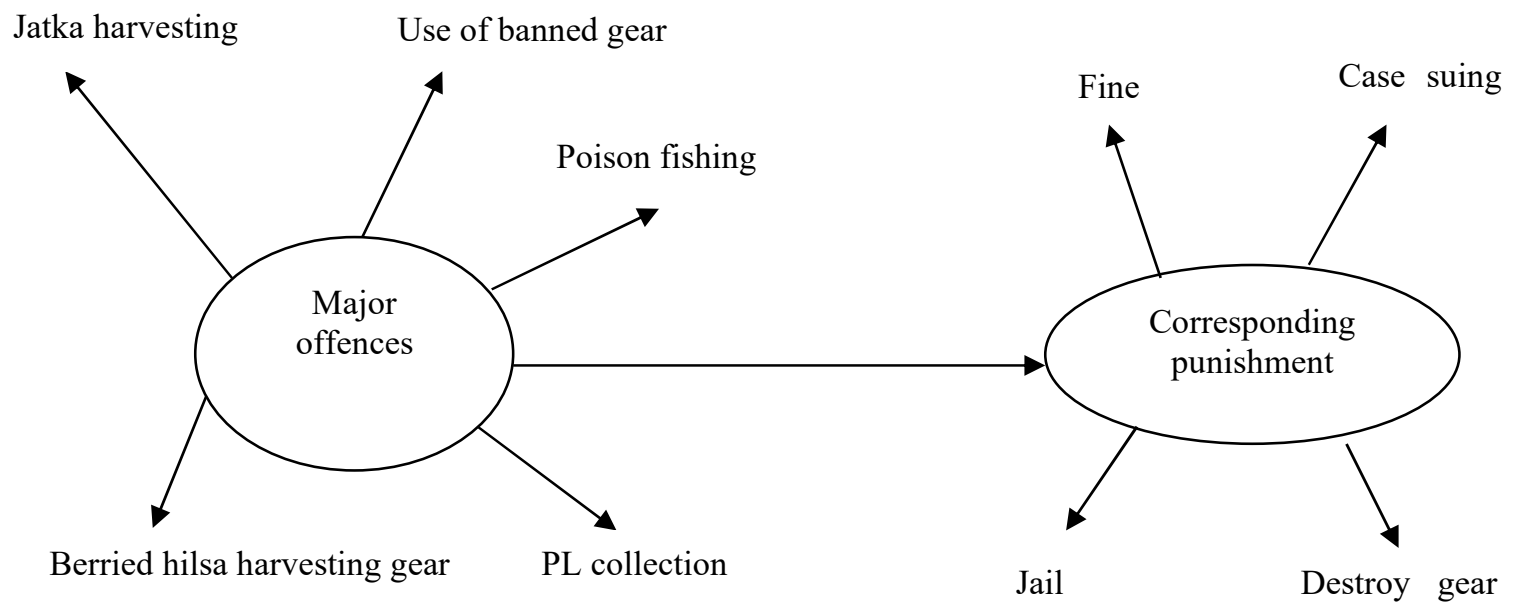

Figure 1. Major fishing offences and corresponding punishment in Sharankhola, Bagerhat.

\subsection{Fisheries Production in the Sundarbans:}

The production figures collected by the FD show sharp fluctuations from year to year and cannot be used to gauge the possible status of stocks. Estimates of the annual SRF fishery landed harvest vary considerably and a summary of available information is highlighted in Table 2. Amount of harvested fish were lowest $(1,108.63 \mathrm{t})$ in 2005-06 and showed an increasing trend up to 2007-08. The highest fish harvest was recorded in 2007-08 
$(4,203.64 \mathrm{t})$ and abruptly declined in 2009-10 (1,119.55 t). The harvested amount of bivalves showed a decreasing trend from 2005-06 up to2009-10. The highest harvested amount of bivalves was recorded in 2005-06 $(1,078.70 \mathrm{t})$ and lowest was in 2009-10 (0.11 t).

Table 2: Estimates of annual fish harvest of the Sundarbans, Bangladesh.

\begin{tabular}{|c|c|c|c|c|}
\hline \multirow{2}{*}{ Year } & \multicolumn{2}{|c|}{ Fish } & \multicolumn{2}{c|}{ Bivalve } \\
\cline { 2 - 5 } & Harvest (t) & Revenue (Tk.) & Harvest (t) & Revenue (Tk.) \\
\hline $2005-06$ & $1,108.63$ & $39,43,505$ & $1,078.70$ & $1,45,790$ \\
\hline $2006-07$ & $1,442.96$ & $45,90,021$ & 53.10 & 32,600 \\
\hline $2007-08$ & $4,203.64$ & $1,29,06,318$ & 38.81 & 25,740 \\
\hline $2008-09$ & $3,539.31$ & $98,05,040$ & 0.41 & 400 \\
\hline $2009-10$ & $1,119.55$ & $52,65,808$ & 0.11 & 150 \\
\hline
\end{tabular}

Source: Forest Department, 2010

\subsection{Fisheries production at Sarankhola, Sundarbans:}

The harvested amount of white fish was higher 622.04 $\mathrm{t}$ in 2011-12 than 592.11 t in 2010-11. The harvested amount of hilsa was 382.93 $\mathrm{t}$ in 2010-11 and 182.18 $\mathrm{t}$ in 2011-12 (Table 3). The harvested amount of prawn was 552.51 $\mathrm{t}$ in 2010-11 and 300.13 $\mathrm{t}$ in 2011-12. The harvested amount of hilsa and prawn was lower in 2011-12 than in 2010-11.

Table 3: Estimates of the annual fish harvest of Sharankhola, Sundarbans in the recent years.

\begin{tabular}{|c|c|c|c|}
\hline \multirow{2}{*}{ Year } & \multicolumn{3}{|c|}{ Harvested amount (ton) } \\
\cline { 2 - 4 } & White Fish & Hilsa & Prawn \\
\hline $2010-11$ & 592.11 & 382.93 & 552.51 \\
\hline $2011-12$ & 622.04 & 182.18 & 300.13 \\
\hline
\end{tabular}

Source: Forest Department, Sharankhola, 2012

\subsection{Major problems and challenges}

3.7.1 Number of fishers and unsustainable extraction: The number of fishers has increased over the years in the Sundarbans. There is hardly any reliable information on the number of fishers and fishing boats. The number of fishers and fishing boats are generally believed to be far exceeding the carrying capacity of the locality.

3.7.2 Use of destructive gear (Badha jal/ Behundi jal): Several studies have determined that set bag net fishing is highly destructive to natural resources (Islam et al. 1993; Khan et al. 1994, Kamrul et al. 2015). These nets are still widely used for harvesting PL of shrimp. This is because during periods when fishing is banned, fishers have no other options for livelihood. The destructive gear is a major cause of decline in fisheries. It takes out the hatchling, fry, fingerling and juvenile of many large and medium size species. They do not get opportunity for growing up to marketable size and it is a constraint in increasing the biomass.

3.7.3 Post-larvae (PL) collection: Locally known, small version of SBN with fine mesh and is well known for SRF in taking out PL of Golda and Bagda. There are thousands of Net Jal (smaller version of set bag net with fine mesh) users collecting golda (Macrobrachium rosenbergii) and bagda (P. monodon) PL in the season and some are year round (using push and pull type net) in small quantity. It is very destructive to the fisheries as it kills eggs, spawn, hatchling and fry of all small and large species while fishers scoop out the PLs.

3.7.4 Poison fishing: In the present study, highly toxic agricultural pesticides are used as poison fishing materials. Sembush (Cypermethrine), Ripcord (Cypermethrine) and Dhalai are used for poison fishing. The first two are used for shrimp and dhalai is for white fish. There are other two poisons, Cythrine (Cypermethrine) and Carette (Lamdacyhelothrine) also used for fishing (NFB 2009). It is a highly destructive fishing method used in the canals of the Sundarbans. The poison fishing is very detrimental to the fisheries as it affects to all aquatic organisms. The poison fishing causes huge fisheries damage.

3.7.5 Over fishing and maximum sustainable yield (MSY): Over fishing is rampant and some of the SRF fish species are over exploited. Regaining of the exploited species and protection of other species is essential for sustainable fisheries. Otherwise the fisheries would collapse in the long run and regaining would be difficult. There is no recent estimates of the stock of fisheries resources in the SRF except Chantarasri (1994) and Smith (1995). They estimated the population parameters and optimum yield of some commercially important species in the SRF.

3.7.6 Habitat degradation and loss of habitat: The habitat degradation is taking place in the SRF. It includes river bank erosion, silting up of rivers, canals and beel/chatal, and decrease of water depth, etc. The habitat degradation has significant negative impact to the SRF fisheries. The siltation of rivers in the upstream reduces the fresh water flow and increases the salinity intrusion which may affect/change the biodiversity in the SRF and adjoining areas. The decrease of water depth limits the movement of fish for breeding, nursing, feeding, shelter, environmental adaptation and hence contributes to fisheries decrease. 
3.7.7 Jatka fishing: This fishing takes out huge number of juvenile hilsa limiting their growth due to recruitment over fishing. Because of Hilsa Fisheries Management Policy implementation by the Govt. jatka fishing has reduced significantly.

3.7.8 Lack of awareness and compliance to fishing rules and regulations: The fisher, community, local public representatives, civil society people, money lenders, NGOs working in the area are not well aware of the existing fisheries rules and regulations. Sometimes if they know the rules, they do not know the definition or the area/time of ban. Thus fishing is going on violating the rules and regulations and a major cause the fisheries decrease. Capacity building to awareness and compliance to fisheries rules and regulations are essential in the study area.

3.7.9 Coastal pollution: Frequent oil leakage and regular washing of increasing numbers of petrol/dieseloperated trawlers and vessels is causing water pollution near local sand heads. It is suspected by local fishermen as an important factor for recent lack of fish gathering in some fishing spots. After commencement of Bogi to Mongla water route (shown below) the rate of oil leakage increased substantially.

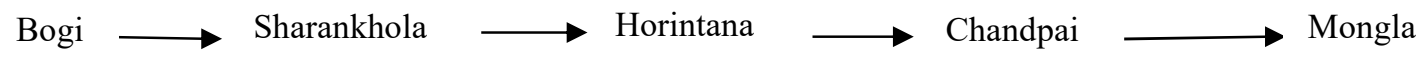

3.7.10 Unprotected five restricted canals: The FD declared five canals as sanctuaries in the study area where fish catching has been completely banned. Unfortunately these canals are totally unprotected due to lack of man power of the FD. As a result some fishermen harvest fish from those five restricted canals.

3.7.11 Inadequate collaboration among department: To achieve particular goal it is very essential to have integrated collaboration with multiple agencies. But in the study area integration and collaboration among multiple agencies are weak. As a result various offences are occurring at the study area.

Sharankhola Co-management Organization (SCMO) was formed on 12 April, 2010. So, the achievement by the SCMO on sustainable fisheries management in the study area is at the beginning stage. Total areas where SCMO working is about 31,227 ha. It covers one Range office, three Station offices, one Upazila, two Unions, and 20 villages/paras. Significant of co-management activities in the study area included awareness raising, alternate income generation, eco-tourism and efforts towards social mobilization. The key regulatory measures and steps of co-management included limited Boat License Certificate (BLC), protection of berried hilsa and protection of jatka.

Co-management approaches to natural resource management are recognized in many areas of the world (Ostrom 1990, Bromley 1992, Borrini-Feyerabend et al. 2000, Sharma 2011). In Bangladesh the co-management approach was introduced only in 2005. Co-management and adaptive management complement one another. Cases from Canada and Sweden, traced over time spans of 2-3 decades, indicate that co-management as problem solving enables parties to transfer learning from one situation to another, and tackle increasingly more complex problems (Olsson et al. 2004, Carlsson and Berkes 2005). SCMO is taking various initiatives, preventive and regulatory measures for sustainable fisheries management in the study area.

Very few study reports exist in context of IRMP in the Sundarbans. Near-shore fisheries of the Sundarbans ecosystem are believed to be overexploited. The reason of this over exploitation is due to extensive use of destructive set bag nets for extensive shrimp PL collection and this is also causing damage to the nursery grounds of many species, and to newly planted mangroves as well as reserve forests (Hoq 2000). Though laws regarding best fishing practices exist, but fishers' awareness to appropriate practices (fishing methods, tools, seasons, laws and so forth) is low.

Shah et al. (2010) stated that the FD highlights that the increase in number of offences could be due to the large number of fishers now moving to the Sundarbans Tiger Reserve (STR) area to fish, as there is not much fish available outside the area. The increased number of sueing case in the recent years supported that the offences are increasing in the study area.

The fisheries of SRF shows a declining trend. There is no reliable and chronological information on the production of the SRF. The FD record shows 27\% (calculated from Hoq 2008 quoting Divisional Forest Office, Khulna), decrease in 2002 as compared to 1995. IPAC reported 58\% (Biswas 2009, Ghosh 2009) reduction during the last 40 years. The fishers' and community peoples' perception is about $40-50 \%$ reduction of catch in the last 10 years. The reduction is low in the lower SRF (30-40\%) and high $(50-60 \%)$ in upper SRF. The reduction of hilsa production might be due to siltation, rising of river beds and forest floor in the Sundarbans. The reduction of shrimp production might be due to indiscriminate wild PL collection.

\section{Conclusion}

IRMP was developed for sustainable fisheries management which provided two major types of guideline for sustainable fisheries management. One focused on fisheries resources conservation measures including fishing area ban, fishing ban during breeding season, seasonal gear ban, complete gear ban, mesh size control, boat license certificate (BLC) limit, fishing duration, fish size limit and species ban. The implementation of resource conservation measures by the FD is minimum. Other set of guidelines focused on fisheries improvement 
measures, such as, habitat restoration, establishing fish sanctuaries, popularizing pond aquaculture, awareness raising, fisheries stock assessment and production trend, fisheries marketing, livelihoods opportunities and regular production monitoring. These improvement measures are also poor in the study area

The Sundarbans fisheries resource is not only a great resource for Bangladesh but it is a world heritage as well. It provides livelihoods to a huge numbers of people. It is important from the view point of ecology, environment, economics, nutrition, sociology and culture of a big group of people in the periphery of the forest. It is an important breeding and nursery ground of a wide range of estuarine, offshore, marine fishes and shrimps. The resource is being degraded due to lack of proper management. So, effective co-management activity is essential for sustainable fisheries resources conservation-management in the Sundarbans.

\section{Recommendations}

Based on the general observation as well as major problems and challenges discussed in the results and discussions the following recommendations are made:

- $\quad$ Fisher numbers should be limited for sustainable fisheries conservation-management in the Sundarbans.

- An appropriate act is to be formulated so that industry owners cannot produce destructive gears.

- Put complete ban on shrimp PL collection for reducing pressure on sundarbans fisheries resources.

- Appropriate field test kit is urgently needed to monitor presence of poison in the water while fishers are fishing.

- Update stock assessment MSY estimates are essential for controlling overfishing.

- Awareness raising program by the co-management authorities should be increased.

- The planning of activities and implementation of co-management should be a continuous process.

- Holistic and proper implementation of govt. laws and regulations by the concerned authority is essential.

- Prepare a National Policy for Eco-tourism in the Sundarbans, so that fishermen engaged to tourism instead of fishing.

- Strong vigilance by the FD is needed to curb illegal and unreported fishing from five canals (sanctuaries).

- Increase strong coordination among all concerned agencies for conservation and sustainable management of Sundarbans fisheries.

- The alternate income generating activities (AIGAs) are very minimum in the study area. The government needs to support more AIGAs during the periods when fishing is restricted.

- For reducing water pollution due to frequent oil leakage it is needed to restart Rampal route instead of Bogi to Mongla route.

Acknowledgements: Financial support by the Integrated Protected Area Co-management (IPAC) project of Bangladesh is gratefully acknowledged. The authors also wish to thank Professor Dr. Md. Abu Sayeed, Sylhet Agricultural University. The authors expressed their deep gratification to Golam Murtoza (Rabbi), Site Facilitator, IPAC Sarankhola; Kanai Lal, WorldFish Centre, Khulna and Kashyapy Bikash Chandra, Assistant Conservation of Forest, Sarankhola Range for providing valuable information. The authors are also grateful to Prof. Dr. Niaz Khan, University of Dhaka and Dr. M.G. Mustafa, Senior Fisheries Coordinator, WorldFish Centre, Dhaka for their advice and guidance throughout the process of developing this paper.

\section{References}

Bisaws, F. (2009). Participatory Rural Appraisal of Sundarbans East Wildlife sanctuary, June 2009, IPAC.

Borrini-Feyerabend, G., Michel, P., Farvar, M.T., Kothari, A. and Renard, Y. (2004). Sharing Power. Learning by doing in co-management of natural resources throughout the world. IIED and IUCN/CEESP/CMWG, Cenesta, Tehran.

Borrini-Feyerabend, Farvar, M.T., Nguinguiri, J.C. and Ndangang, V.A. (2000). Co-management of Natural Resources: Organizing, Negotiating and Learning-by-Doing. The World Conservation Union (IUCN): Gland, Switzerland.

Bromley, D. (ed). (1992). The commons, property and common property regimes in making the commons work: theory, practice and policy. Institute of Contemporary Studies, San Francisco.

Canonizado, J.A. and Hossain, A. (1998). Integrated Forest Management Plan. Forest Department, Dhaka, Bangladesh.

Carlsson, L. and Berkes, F. (2005). Co-management: concepts and methodological implications. Journal of Environmental Management, 75: 65-76.

Chantarasri, S. (1994). Fisheries Resources Management for Sundarbans Reserved Forest. Integrated Resource Development of the Sundarbans Reserved Forest, Bangladesh. BGD/84/056, UNDP and FAO.

Ghosh, G. (2009). Site level field appraisal report of Sundarbans west Wildlife sanctuary, August 2009, IPAC. 
Haq, M.E, Islam, M.N., Kamal, M. and Wahab, M.A. (2003). Fisheries structure and management implications in the Sundarbans mangrove reserve forest, Bangladesh. Indian J. Fish, 50(2): 243-249.

Hoq, M.N. (2008). Sundarbans Mangrove: Fish and Fisheries. Graphic media, 85 Fakirapool, Dhaka.

Hoq, M.E. (2000). Fisheries in the Sundarbans Mangrove Ecosystems of Bangladesh. Aquaculture Beyond 2000-going global. Aquaculture Asia. Vol. V, No.4, October-December.

IRMP (Integrated Resources Management Plans). (2010). Integrated Resources Management Plans for the Sundarbans. Forest Department, Ministry of Environment and Forests, Dhaka, Bangladesh.

Islam, M.S., Khan, M.G., Quayum, S.A., Sada, M.N.U. and Chowdhury, Z.A. (1993). The Estuarine Set Bag Net Fishery. In: Studies of Interactive Marine Fisheries of Bangladesh. Bay of Bengal Programme: Madras, India. BOBP/WP/89. 19-50.

IUCN (Internation Union for Conservation of Nature). (1994). Mangroves of the Sundarbans. Vol. 2: Bangladesh. The IUCN Wetlands Programme. IUCN, Gland, Switzerland.

Kamal, M. (1999). Assistance to Fisheries Research Institute - A Report Prepared for the "Assistance to Fisheries Research Institute'. Consultancy report on Marine Fisheries Resource Management. BGD/89/012. FRI-GOB/UNDP/FAO.

Md. Kamrul Islam, Sk. Ahmad-Al-Nahid, Md. Sadequr Rahman Khan, Md. Emranul Ahsan, Kazi Ahsan Habib, Mir Mohammad Ali (2015). Fishing gears used by the Fishers at Rupsha River in Khulna District, Bangladesh. International Journal of Fisheries and Aquatic Studies; 4(1): 29-33.

Khan, M.G., Islam, M.S., Mustafa, M.G., Sada, M.N.U. and Chowdhury, Z.A. (1994). Bio-socioeconomics assessment of the effect of the estuarine set bagnet on the marine fishes of Bangladesh. Bay of Bengal programme: Madras, India. BOBP/WP/94. $28 \mathrm{pp}$.

NFB (New Forum Bangladesh). (2009). Incidents of fish poisoning on the rise near Sundarbans. News published on November 14, 2009. Information source: http://www.bangladesh-web.com

Olsson, O., Folke, C. and Berkes, F. (2004). Adaptive co-management for building resilience in socialecological systems. Environmental Management, 34:75-90.

Ostrom, E. 1990. Governing the commons: The evolution of institutions of collective action. Cambridge University Press: Cambridge.

Rabbani, A.G. and Sarker, M.S. (1997). Study on the current status of the fish extraction and revenue collection from the Sundarbans reserve forest. Project Thesis, 1997, Fisheries Marine Resource Technology Disipline, Khulna University, Bangladesh.

Rosario, E.A. (1997). The Conservation Management Plan of the Wildlife Sanctuaries in the Sundarban Forests. Mandala Agricultural Development Corporation, Dhaka, Bangladesh.

Shah, S., Huq, K. A. and Rahaman, S.M. B. (2010). Draft report on Study on the conservation and management of fisheries resources of the sundarbans. IPAC, Bangladesh.

Sharma, R. (2011). Co-Management of Protected Areas in South Asia with special reference to Bangladesh. Asia-Pacific Journal of Rural Development, 11(1):1-28.

Smith, C. (1995). Integrated Resource Development of the Sundarbans Reserved Forest. Further Analysis of the Fisheries Data, FAO/UNDP Project, Khulna University, Khulna, Bangladesh. 